\title{
Synergism between Iron and Magnesium in Enteral Feeding Formulation Optimized for the Availability of Minerals by Response Surface Methodology
}

\author{
Luciana Bueno \\ Divisão de Ciência dos Alimentos Departamento de Alimentos e Nutrição Experimental Faculdade de Ciências Farmacêuticas, \\ Universidade de São Paulo Av. Lineu Prestes, 580 CEP: 05508-900 São Paulo, SP, Brasil
}

\begin{abstract}
Enteral feeding is the nutrition therapy usually to substitute the traditional diet for those patients who need to be fed by probe. This work's aim was to study the effect of the components: fiber, calcium and medium-chain triglycerides in iron and magnesium availability for seeking optimize a formulation by two minerals. The analysis of multiple variables was usage and when the level curve was obtained it could be verified of the three nutrients together was the one that presented more synergism for the appraised formulation for iron and magnesium.
\end{abstract}

Keywords Iron, Magnesium, Experimental Design

\section{Introduction}

Minerals are nutritious essential for the accomplishment of more than a hundred enzymatic processes, besides they exercise functions in the macronutrients synthesis and in physiologic processes in the human organism[1-6]. The bioavailability of minerals is usually defined by the measure of the proportion of the total of the element contained in the food, meal or diet that it is used for the normal maintenance of the functions of the organism[4-6].

The chemical structure of fibers contains fitates and oxalates, for instance, they act of form interference for the readiness of the iron and of the zinc in diets and foods. The calcium impedes the absorption of iron and magnesium in amounts still no known, what would increase the possibility to harm the use minerals[6].

Some authors, to the they study several types of diets and foods with the purpose of measuring the availability of the iron in different concentrations and components, comparing the methods in vitro and in vivo, they showed a correlation significant for the iron, showing that the methods in vitro they reproduce the conditions of the human digesting system and they are capable to predict the absorption mechanisms of nutritious[1-7].

The aim of this work have been study the effect of medium-chain triglycerides (TCMs), of fiber and of calcium in the availability of iron and magnesium in the simultaneous

* Corresponding author:

lubuenno@yahoo.com.br (Luciana Bueno)

Published online at http://journal.sapub.org/food

Copyright (C) 2012 Scientific \& Academic Publishing. All Rights Reserved maximization of enteral feeding for two minerals by in vitro method.

\section{Methodology}

\section{Materials}

The ingredients that composed the appraised formulations in the study were obtained according to the marketed modules; isolated soy protein, maltodextrin, canola, corn and TCM oils, mixes of mineral and vitamin salts (Table 1).

Table 1. Experimental Enteral Feeding

\begin{tabular}{cc|c}
\hline Components & $100(\mathrm{~g})$ & $1000 \mathrm{~mL}^{1}$ \\
\hline $\begin{array}{c}\text { Total Protein (g) } \\
\text { Soy Protein Isolate }\end{array}$ & 13.34 & 31.00 \\
\hline $\begin{array}{c}\text { Total Carbohydrates (g) } \\
\text { Maltodextrin }\end{array}$ & 59.12 & 137.40 \\
\hline Fat (g) & & \\
Canola oil & 7.74 & 18.00 \\
Corn oil & 5.38 & 12.50 \\
TCM & 1.93 & 4.50 \\
Soy Lectin & 1.30 & 3.00 \\
\hline Minerals (g) & & 5.00 \\
Salt Mixture & 2.15 & 1.00 \\
Calcium Carbonate & 0.43 & 10.00 \\
\hline Vitamins (g) & & \\
Vitamin Mixture & 4.30 & 10.00 \\
\hline Fiber (g) & & 767.60 \\
\hline Partially hydrolyzed guar & 4.30 & 1000.00 \\
gum & 100.00 & \\
\hline Water (g) & & \\
\hline Total (g) & & \\
\hline
\end{tabular}

${ }^{1} 1000 \mathrm{~mL}$ of feeding diet as $232,4 \mathrm{~g}$ power 


\section{Experimental Desing}

Seven experimental diets were elaborated, to adapt the study to the mathematical model by Response Surface Methodology[9-10] for mixture of three components. Different amounts of corn oil and of maltodextrin they were used to maintain the value energy total of the experimental diets $(1011.0 \mathrm{kcal} / \mathrm{kg})$ and $(232.4 \mathrm{~g}$ of powder for $767.6 \mathrm{~g}$ of water) the final dilution.

\section{Analytical Methods of Iron and Magnesium in Enteral Feeding \\ Iron and Magnesium in Enteral Feeding}

The analytical procedures were accomplished according to the norms proposed by AOAC[11]. For the determination of the concentrations of iron and magnesium presents in experimental formulations the method of Espectrometric of Atomic Absorption (EAA) was used for determination of minerals. The readings of the samples and of the curves patterns they were accomplished in Polarized Zeeman AAS Hitachi Z-5000.

\section{Iron and Magnesium Availability in Enteral Feeding}

The method has been used for Miller modified by Luten et al.[8] by the determination of the availability of iron and zinc, and in this work is used by magnesium availability. The enteral feeding was submitted to the digestion with pepsin, after acidification of the middle with $\mathrm{HCl} 6 \mathrm{~N}$ until reaching $\mathrm{pH} 2$, following by digestion with pancreatin/bile, after the alkalization of the middle to $\mathrm{pH} 7$ with $\mathrm{NaHCO}_{3}$ contained in dialysis tubes.

\section{Statistical Analysis}

Being treated of a powdered formulation for enteral feeding, the variables should obey the relationship $\sum_{i=1}^{q} \mathrm{x}_{\mathrm{i}}=$ $1,0=100 \%$ and variables selected in this study were TCM $\left(\mathrm{x}_{1}\right)$, Fiber $\left(\mathrm{x}_{2}\right)$ and Calcium $\left(\mathrm{x}_{3}\right)$. Analysis of variance and analysis of regression have been was used to evaluate the quality of the adjustment of the mathematical model and the test Qui-square was applied corrected by the experimental proportion for validation[13-16]. The data were analyzed by the program Statistica $6.0[17]$, being the differences considered significant when values of $p<0.05$.

\section{Results}

Table 2. Dializability of Iron (\% FeD) and Magnesium (\% MgD) with $\mathrm{TCM}$, fiber and calcium in experimental desing

\begin{tabular}{cccccc}
\hline Diets & TCM & Fiber & Calcium & $\begin{array}{c}\text { Mean }(\% \\
\text { FeD })\end{array}$ & $\begin{array}{c}\text { Mean }(\% \\
\text { MgD })\end{array}$ \\
\hline 1 & 1 & 0 & 0 & $5.40(0.44)$ & $3.60(1.00)$ \\
2 & 0 & 1 & 0 & $4.32(0.10)$ & $11.05(2.22)$ \\
3 & 0 & 0 & 1 & $1.25(0.18)$ & $9.04(0.10)$ \\
4 & 0.5 & 0.5 & 0 & $5.50(0.49)$ & $5.80(0.69)$ \\
5 & 0 & 0.5 & 0.5 & $6.90(0.64)$ & $11.05(1.30)$ \\
6 & 0.5 & 0 & 0.5 & $4.90(0.64)$ & $5.38^{(*)}(0.06)$ \\
7 & 0.33 & 0.33 & 0.33 & $5.70(0.33)$ & $13.27^{(*)}(2.21)$ \\
\hline
\end{tabular}

$\mathrm{n}=3^{(*)} \mathrm{n}=2$ ( ) Standart Deviation
Table 3. Factors of variation for the responses of iron and magnesium dializabilities in enteral feeding formulation

\begin{tabular}{cccc}
\hline Nutrients & $\mathrm{F}$ & $\mathrm{p}^{* *}$ & $\mathrm{R}^{2}$ \\
\hline Iron & 39.08 & 0.0000 & 0.91 \\
Magnesium & 21.60 & 0.0000 & 0.82 \\
\hline \multicolumn{4}{c}{ (**) probability significant level of $95 \%(\mathrm{p}<0.01)$}
\end{tabular}

The availability of iron and magnesium obtained by the established conditions in the experimental design are represented in Table 2 and in the Table 3 who presents the variation factors obtained by the variance analysis for each one of the mathematics models. It can be observed the values of $\mathrm{F}$ and the level of statistical $p$ and the determination coefficient $\mathrm{R}_{2}$ by ANOVAs coefficients for to verify the adaptation of the models to the appraised answers for each one of the two minerals. The values obtained for the estimate of the answer $\hat{y}=" \%$ iron availability" they were used for the obtaining of a quadratic model adjusted by the experimental data, to predict the answer with the three nutrients studied in the experimental design. The Equation (1) presents the coefficients of regression of the quadratic model adjusted by the experimental data for the iron and their respective standard mistakes, dear for the experimental data.

$\hat{y}=5.58 x_{1}+4.50 x_{2}+1.30 x_{3}+5.32 x_{1} x_{3}+15.42 \mathrm{x}_{2} x_{3} E q(1)$

$$
\text { (0.31) (0.31) (0.34) (1.57) (1.57) }
$$

The Figure 1 presents the outline curves obtained for the response $\hat{y}=" \%$ iron availability" for the 3 variables $\left(x_{1}, x_{2}\right.$, $\left.x_{3}\right)$, in which it is observed that the largest values of $\hat{y}(x)$ they are associated to the interaction fiber and calcium.

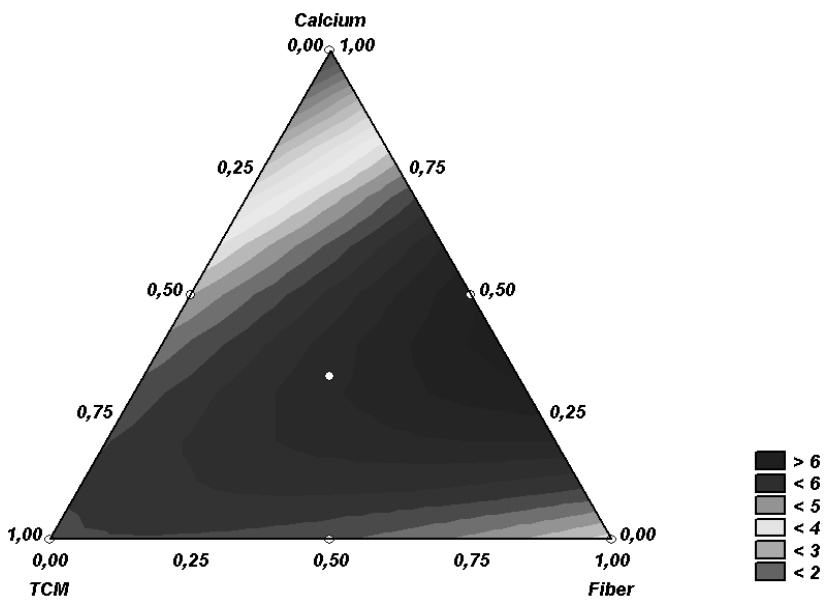

Figura 1. Level curves for iron dializability response

For the magnesium response $\hat{y}=" \%$ magnesium availability" it was obtained the special cubic model adapted by the experimental data to predict the regression coefficients and the standard error, as display the Equation 2.

$$
\begin{gathered}
\hat{y}=9.30 x_{1}+2.83 x_{2}+11.00 x_{3}+162.52 x_{1} x_{2} x_{3} E q \\
(0.84)(0.84)(0.83)(34.46)
\end{gathered}
$$

Those coefficients presented values of $\mathrm{b}{ }_{1} \mathrm{x}_{1}, \mathrm{~b}{ }_{2} \mathrm{x}_{2}, \mathrm{~b}{ }_{3} \mathrm{x}_{3}$ and $\mathrm{b}^{*}{ }_{123} \mathrm{x}_{1} \mathrm{x}_{2} \mathrm{x}_{3}$ where $\mathrm{b}^{*}>0$, that it meant a synergism between the selected variables and the appraised response, showing a combination among the nutrients aggregates to the tertiary interaction. 
The Figure 2 comes the level curves that represent the outlines obtained for the response $\hat{y}(x)=" \%$ magnesium availability" for the three variables $\left(\mathrm{x}_{1}, \mathrm{x}_{2}, \mathrm{x}_{3}\right)$, in which it is observed that the values of $\hat{y}(x)$ they are associated to the $\mathrm{TCM}$, fiber and calcium. The Figure 3 presents the maximization of the formulation proposed in the united optimization of the empiric models for the iron and magnesium availability in agreement with the balances obtained in the quadratic (iron) and cubic models special (magnesium), adapted by the experimental data. The Figure 4 displays the values of profiles for predicted values and desirability obtained by the united optimization for the two minerals. The Table 4 displays the obtained balances of the reproductive values in the proportions of $32.5 \%$ of fiber and TCM and $35.0 \%$ of calcium that show variations among the nutrients TCM, fiber and calcium. The Table 5 displays the values of TCM, fiber and calcium of the experimental diet in comparison with diet that was optimized by the balances obtained by the applicability of the experimental design to predict the availability of the two minerals in united optimization.

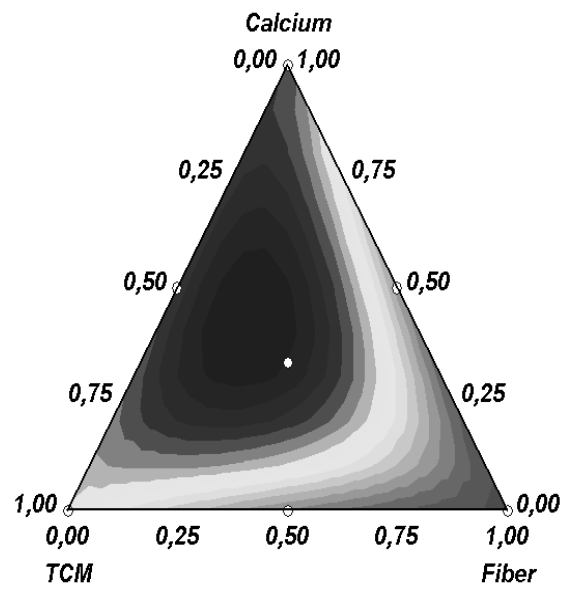

Figura 2. Level curves for magnesium dializability response
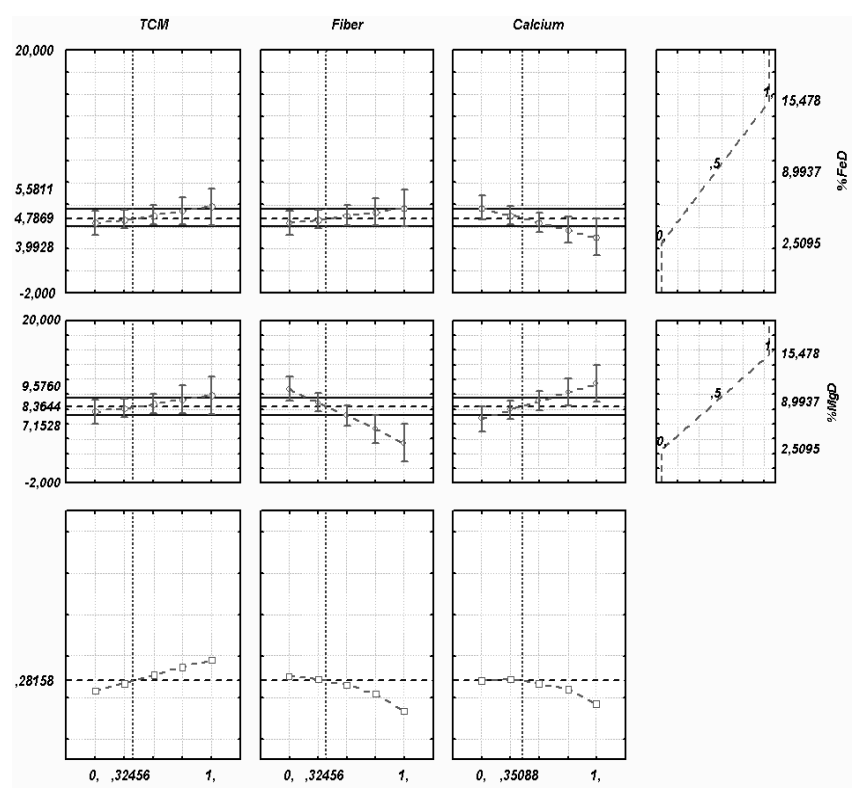

Figura 3. Predictive values of iron and magnesium dializability

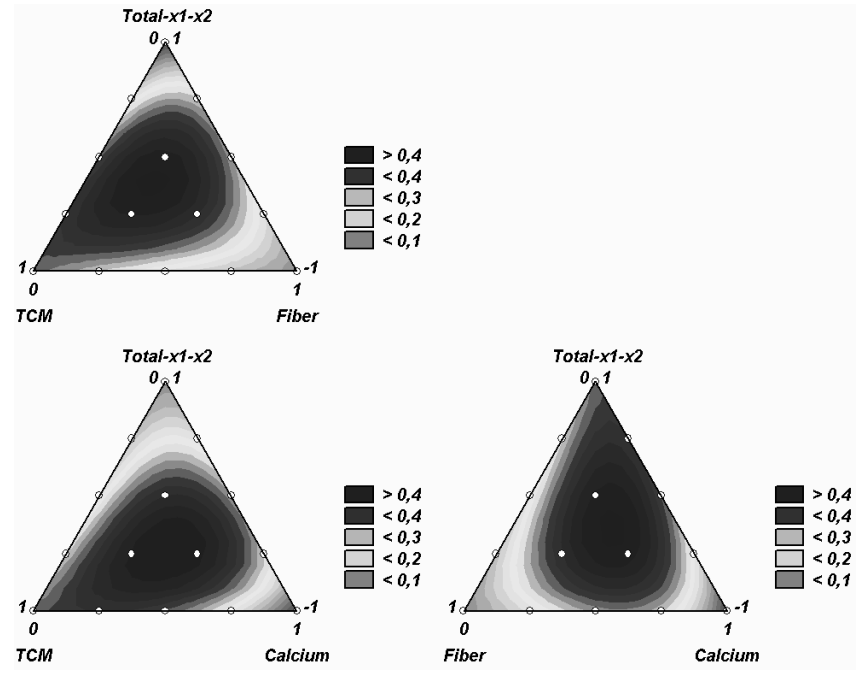

Figura 4. Levels curves for iron and magnesium dializabilities responses and predictives values for two minerals

Table 4. Values of Percentage of iron and magnesium dializabilities by formulation with the concentrations of $32.5 \%$ of TCM and of fiber and of $35.0 \%$ of calcium

\begin{tabular}{cccc}
\hline Nutrients & $\mathrm{n}$ & $\begin{array}{c}\text { Total Quantity } \\
(\mathrm{mg} / \mathrm{L})\end{array}$ & $\begin{array}{c}\text { Percentage of dializability } \\
(\%)\end{array}$ \\
\hline Ferro & 3 & $13.00(0.55)$ & $5.70(0.40)$ \\
Cálcio & 3 & $240.00(15.96)$ & $10.00(0.70)$ \\
\hline
\end{tabular}

() Standart Deviation

Table 5. Enteral Feeding: Experimental diet and optimized diet for porcentage of iron and magnesium dializabilities

\begin{tabular}{ccc}
\hline Components & Experimental Diet & Optimized Diet \\
\hline Protein $(\mathrm{g})$ & 31.0 & 31.0 \\
Carboidrate $(\mathrm{g})$ & 138.0 & 142.2 \\
Fiber $(\mathrm{g})$ & 10.0 & 5.5 \\
Corn oil $(\mathrm{g})$ & 12.5 & 11.5 \\
Canola oil $(\mathrm{g})$ & 18.0 & 18.0 \\
TCM $(\mathrm{g})$ & 4.5 & 5.5 \\
Soy lecitin $(\mathrm{g})$ & 3.0 & 3.0 \\
Calcium $(\mathrm{mg})$ & 400.0 & 280.0 \\
Iron $(\mathrm{mg})$ & 10.0 & 10.0 \\
Zinc $(\mathrm{mg})$ & 3.6 & 3.6 \\
Magnesium $(\mathrm{mg})$ & 115.3 & 115.3 \\
Vitamin C $(\mathrm{mg})$ & 50.0 & 50.0 \\
Total $(\mathrm{g})$ & 1000.0 & 1000.0 \\
\hline & &
\end{tabular}

\section{Discussion}

All of the regression models (lineal, quadratic and cubic special) for the values of iron and magnesium availability were shown highly significant $(\mathrm{p}<0.05)$. Among all of the synergic effects observed for the iron availability, the most pronounced effect was of the interaction binary fiber and calcium. For they be highly fermentable, they act through the bacterial lawsuit in the colon and they present a ligation capacity with minerals, mainly with the calcium, the soluble fibers have been recommended in enteral feeding[21].

For the magnesium, it has been reported that its dietary absorption averages $\approx 45 \%$ being the $55 \%$ remaining excreted in faeces[20-22]. Like other divalent cations the entry of magnesium from the intestinal lumen occurs by two 
mechanisms: a saturable facilitated mechanism (intracellular pathway) operating at low intraluminal concentrations and a paracellular pathway throughout the whole length of the small bowel when intraluminal concentrations are high [19-22]. The absorption of magnesium and calcium is influenced by the solubility of element compounds in the absorption site and/or body status of individuals in these minerals. In the case of the calcium, this mineral has to be liberated in a soluble form during the digestion process. It has been reported that the absorbed calcium fraction varied inversely with the calcium intake although the whole amount of absorbed element enhances[21-22].

The gum guar is more important than other types of fibers in the production of short-chain triglycerides for they act in the intestinal micro flora in human[22]. Other authors observed that patients with paralytic ileum showed smaller diarrhea incidence and smaller compromising of the intestinal functions, submitted to the nutrition enteral with soluble fiber[23]. The interactions of $\mathrm{Fe}^{2+}, \mathrm{Ca}^{2+}$ and $\mathrm{Fe}^{3+}$ in enteral feeding through methods in vitro simulating digestive conditions in different concentrations of soluble and insoluble fiber in the diets and different $\mathrm{pHs}$ have been observed that high quantities of fiber and physiochemical conditions no appropriate they reduce the absorption of minerals in the human organism. The availability of calcium was $2.50 \%$ on average and it suffered interferences due to presence the larger quantities of fiber in foods and diets[24]. Effects of fibers to appraise the availability of iron, calcium and zinc, for methods in vitro and in vivo have been observed the formation of colloids and complex of difficult hydrolysis that influence of nutrients bioavailability in foods[25]. The bioavailability of calcium and iron in leaf vegetables by in vitro method for dialysis of minerals have been observed which the chemical structure and components like oxalates, fibers; tannins and acid fitic are the main interference of iron bioavailability[26].

Gaméz et al.[27] to the they appraise the concentrations of magnesium and calcium seric in institutionalized seniors and they ended that there was positive correlation which the quantities of magnesium and fibers, iron, phosphor and calcium presents in the diets consumed by the seniors. That implicates to say that the increase of the ingestion of magnesium in the diet is dose-dependent regarding the nutrients. The positive correlation with the calcium suggested a similar homeostatic regulation between the calcium and the magnesium.

Hunt e Johnson[28] to the they appraise the consumption of magnesium in men and women in comparison with the values of recommendation of magnesium for DRIs, through the metabolic balance of the mineral, they concluded that the estimate of magnesium can be increased due to lack of appraisal of interactions on foods and diets.

The consumption of cow milk in the first childhood can increase the incidence of anemia in children, because the infant formulas presents low bioavailability and density for the iron, excess of proteins and calcium, besides could interfere in the absorption of the iron and other nutrients in formula[27]. To the they appraise the effect of the bioavailability of the calcium, iron and zinc in samples of cow milk fortified or not with the calcium, through the methods in vitro, the balances showed that the own matrix tends to reduce the bioavailability of the calcium, verified in the milks no fortified, what can be explained by the interaction of the calcium with the components of the milk, mainly with the protein of the milk, and formation of insoluble compounds that tend to harm the benefit of the mineral [27-28].

In vivo and in vitro approaches have been performed to determine the bioavailability of divalent elements in human beings. It is known that each method has its limitations. In vitro methods allow measure the mineral fraction previously solubilized from a meal and consequently available for dialysis through a dialysis membrane under simulated gastrointestinal conditions. Some researchers have reported that results obtained from the in vitro studies can be correlated to mineral bioavailability or bioaccessibility determined in the in vivo studies[29-30]. Besides, in vitro studies allow determine the magnesium and calcium available fractions in the gastrointestinal tract for absorption (dialysability), which should be considered as relative indices of bioavailability.

The interaction binary TCM - calcium went other important factor to the availability of the iron. That interaction can be indicating an engine similar to the described, for several authors for the interference between soluble fiber and calcium[21-30]. Like this, foods or diets that contain composed of fewer complexes (as TCMs) structures; they can tie the calcium, in presence of great quantities of the mineral and with that to favor the availability of the iron in the enteral feeding.

Rodrigues et al.[31] they showed that the present fat in the milk, characterized in natural sources of those stencil, it is constituted of reasonable quantities of cholesterol and saturated fat. Toba et al.[32] to the they compare the effects of the components of the milk in the bioavailability of the calcium, mice in growth, they concluded that the mineral presented interactions with the components of the milk due to formation of insoluble compounds tend to reduce the availability of the mineral, showing the interference of the own chemical structure of the milk in the absorption of the calcium.

The tertiary interaction $\mathrm{TCM} /$ fiber/calcium was shown important for the availability of magnesium, due to the synergism observed with the appraised response, indicating that those three present nutrients in ideal conditions for absorption of the mineral. Yang et al.[33] in a metanalise study, in that the use of the fibers was appraised in formulas of enteral feeding, the balances showed that there was reduction of the time of internment hospital in transplanted patients of liver and of patients with abdominal surgical intervention and a control was observed in the transplanted patients of liver for the cases of diarrhea and infection. Velasco-Reynold et al.[34] have been showed the mean magnesium dialysability found in duplicate meals in hospital (daily, lunch, dinner) was $13.2 \%$ per meal. The dark green vegetables and vege- 
tables in general are primary sources of bioavailable magnesium in daily diet. The Mg dialysabilities were only significantly influenced by dialysable calcium, magnesium, zinc, chromium and iron fractions. Consequently, important similarities in the magnesium and calcium behaviours in foods and meals as well as in their absorptive processes exist. The fibre content of duplicate meals did not influence the dialysable calcium fraction and calcium dialysabilities. Dietary fat affects positively the calcium absorption perhaps by the chelating action of fatty acids. Only total magnesium and dialysable magnesium levels and magnesium dialysabilities influenced significantly on dialysable calcium fractions.

\section{Conclusions}

In the response of iron and of magnesium availability in enteral feeding formulation were proportions of $32.50 \%$ of medium-chain triglycerides and fiber and of $35.00 \%$ of calcium. There was a contract among the empiric model of the iron (quadratic) with the one of the magnesium (cubic special) so that it was possible to define the best formulation capable to predict the availability of the two minerals with the participation of the three nutrients selected for the experimental design.

\section{ACKNOWLEDGEMENTS}

I thank College of Pharmaceutics of the University of São Paulo, to the Department of Foods and Experimental Nutrition.

\section{REFERENCIAS}

[1] Harvey, L. Mineral bioavability. The Journal of Nutrition, v. 31, n. 4, p. 179-182, 2001.

[2] Reddy, M B. Hurrel, R F. Cook, J D. Meat Consumption in a varied Diet Marginally Influences Nonheme Iron Absorption in Normal Individuals. The Journal of Nutrition, v. 136, n. 1, p. $576-581,2006$.

[3] Zimmermann, M B. Biebinger, R. Rohner, F. Vitamin A supplementation in children with poor vitamin $\mathrm{A}$ and iron status increases erythropoietin and hemoglobin concentrations without changing total body iron. American Journal of Clinical Nutrition, v. 84, n. 1, p. 580-586, 2006.

[4] Winichagoon, P. Mckenzie, J E. Chavasit, V. Pongcharoen, T. Gowachirapant, S. Boonpraderm, A. A Multimicronutrient-Fortified Seasoning Powder Enhances the Hemoglobin, Zinc, and Iodine Status of primary School Children in North East Thailand: A Randomized Controlled Trial of Efficacy. The Journal of Nutrition, v. 136, n. 3, p. 1617-1623, 2006.

[5] Proulx, A K. Reddy, M B. Iron Bioavailability of Hemoglobin from Soy Root Nodules Using a Caco-2 Cell Culture Model. Journal of Agriculture and Food Chemistry, v. 54, n. 1, p.
518-522, 2006.

[6] Pallarés, I F. Aliaga, I L. Barrionuevo, M. Alférez, M J. Campos, M S. Effect of iron deficiencyon the digestive utilization of iron, phosphorus, calcium and magnesium in rats. British Journal of Nutrition, v. 70, n. 1, p. 609-620, 1993.

[7] Perales, S. Fortification of Milk with Calcium: Effect on Calcium Bioavailability and Interactions with Iron and Zinc. Journal of Agriculture and Food Chemistry, v. 54, p. 4901-4906, 2006.

[8] Luten, J. Crews, H. Flynn, A. Van Dael, P. Kastenmayer, P. Hurrel, R. Deelstra, H. Interlaboratory trial on the determination of the in vitro iron dialysability from food. Journal of the Science of Food Agriculture, v. 72, n. 4, p. 415-424, 1996.

[9] Miller, D D. Schricker, B R. Rasmussen, R R. Van Campen, D. An In vitro method for estimation of iron availability from meals. American Journal of Clinical Nutrition, v. 34, p. 2248-2256, 1981.

[10] Narasinga Rao, B S. Methods for the Determination of Biovailability of Trace Metals: A Critical Evaluation, International Journal of Food Science \&Technology, v. 31, n. 5, p. 353-361, 1994.

[11] Association of Official Analytical Chemistrys. Official Methods of Analysis. Washington, DC: AOAC, 1995.

[12] Reeves, P G. Nielsen, F H. Fahey, JR G C. AIN-93 Purified diets for laboratory rodents: final report of the American Institute of Nutrition ad hoc writing committee on the reformulation of the AIN-76. A rodent diet. The Journal of Nutrition, v. 123, p. 1939-1951, 1993.

[13] Neto, B B. Scarminio, I S. Bruns, R E. Como Fazer Experimentos - Pesquisa e desenvolvimento na ciência e na indústria. 2 ed, Campinas, Editora da UNICAMP, 2001.

[14] Castro, I A. Tirapegui, J. Silva, R S S F. Protein Mixtures and Their Nutritional Properties Optimized by Response Surface Methodology. Nutrition Research, v. 20, n. 9, p. 1341-1353, 2000 .

[15] Cornell, J A. Experiments with mixtures, designs, models and the analysis of mixture data. 2.ed. Nova YorK: John Wiley \& Sons, 1990.

[16] Derringer, G. Suich, R. Simultaneous optimization of several response variables. Journal of Quality Technology, v. 12, p. 214-219, 1980.

[17] Statistica, Data Analysis Software System; Tulsa, USA, 1998.

[18] Pushpanjali K. Khokhar, S. In vitro availability of iron and zinc from some Indian vegetarian diets: correlations with dietary fibre and phytate. Food Chemistry, v. 56, n. 2, p. 111-114, 1996.

[19] Chiplonkar, S A. Agte, V V. Tarwadi, K V. Kavadia, R.. In Vitro Dialyzability Using Meal Approach as na Index for Zinc and Iron Absorption in Humans. Biological Trace Element Research, v. 67, p. 249-255, 1999.

[20] Kahyaoglu, T. Kaya, S. Determination of optimum processing conditions for hot-air roasting of hulled sesame seeds using response surface methodology. Journal of the Science of Food Agriculture, v. 86, n.4, p. 1452-1459, 2006.

[21] Slavin, J L. Greenberg, N A. Partially hydrolyzed guar gum: 
clinical nutrition uses. Nutrition Research, v. 19, n. 6, p. 549-552, 2003.

[22] Velázquez, M. Davies, C. Marett, R. Slavin, J L. Feirtag, J M. Effect of oligosaccharides and fiber substitutes on short-chain fatty acid production by human faecal microflora. Anaerobe, v. 1, n. 6, p. 87-93, 2001.

[23] Spapen, H. Van Malderen, D C. Suys, O E. Huyghens, L. Soluble fiber reduces the incidence of diarrhea in septic patients receiving total enteral nutrition: a prospective, double-blind, randomized, and controlled trial. Clinical Nutrition, v. 20, n.4, p. 301-305, 2001.

[24] Torre, M. Rodriguez, A R. Saura-Calixto, F. Interactions of $\mathrm{Fe}(\mathrm{II}), \mathrm{Ca}(\mathrm{II})$ and $\mathrm{Fe}(\mathrm{III})$ with high dietary fibre materials: a physicichemical approach. Food Chemistry, v. 54, p. 23-31, 1995.

[25] Torre, M. Rodriguez, A R. Saura-Calixto, F. Effects of dietary and phytic acid on mineral availability. Critical Reviews in Food Science and Nutrition, v. 30, n. 1, p. 1-22, 1991.

[26] Gupta, S. Lakshmi, A. Prakash, J. In vitro bioavailability of calcium and iron from selected green leafy vegetables. Journal of the Science of Food Agriculture, v. 86, p. 2147-2152, 2006.

[27] Gámez C. Artacho, R. Ruíz-Lopez, M D. Navarro, M. Puerta, A. López, M C. Serum concentration and dietary intake of $\mathrm{Mg}$ and $\mathrm{Ca}$ in institutionalized elderly people. Science \& Environmental Health Network, v. 203, p. 245-251, 1997.

[28] Hunt, C D. Johnson, L. Magnesium requirements: new esti- mations for men and women by cross-sectional statistical analyses of metabolic magnesium balance data ${ }^{1-4}$. American Journal of Clinical Nutrition, v. 84, p. 843-852, 2006.

[29] Oliveira, M A A. Osório, M M. Consumo de leite de vaca e anemia ferropriva na infância. Journal of Pediatric Gastroenterology and Nutrition, v. 81, n.4, p. 361-366, 2005.

[30] Tso, P. Lee, T. Demichele, S J. Lymphatic absorption of structured triglycerides vs. physical mix in a rat model of fat malabsorption. The American Physiologycal Society, v.277, n. 2, p. 333-340, 1999.

[31] Rodrigues, J N. Gioielli, LA. Anton, C. Propriedades físicas de lipídios estruturados obtidos de misturas de gordura do leite e óleo de milho. Ciência e Tecnologia de Alimentos, v. 23, n. 2, p. 226-231, 2003.

[32] Toba, Y. Tanaka, Y. Tanaka, M. Comparison of the effects of milk components and calcium source on calcium bioavailability in growing male rats. Nutrition Research, v. 19, n. 3, p. 449-459, 1999.

[33] Yang, G. Wu, X. Zhou, Y. Wang. Y. Application of dietary fiber in clinical enteral nutrition: A meta-analysis of randomized controlled trials. World Journal of Gastroenterology, v. 11, p. 3935-3938, 2005.

[34] Velasco-Reynold, C. Navarro-Alarcon, M. Serrana, H L. Perez-Valero, V. Agil, A. Lopez-Martinez, M.C. Dialysability of Magnesium and Calcium from Hospital Duplicate Meals: Influence Exerted by Other Elements. Biological Trace Element Reserach, v. 133, p. 313-324, 2010. 